ノ - Notes

$\left(\begin{array}{ccc}\text { Jpn. J. Hosp. Pharm. } & k \\ 24(1) & 17-22 & (1998)\end{array}\right)$

\title{
Inhibitory Effects of Ticlopidine and Dilazep on Serum-Induced DNA Synthesis in Cultured Rat Renal Mesangial Cells
}

\author{
MASAKO NOMIYAMA, NORIAKI OHNISHI, KAZUKI NAGASAWA and TERUYOSHI YOKOYAMA* \\ Department of Hospital Pharmacy, Kyoto Pharmaceutical University $\dagger$
}

\author{
$\left(\begin{array}{l}\text { Received June 17, } 1997 \\ \text { Accepted September 16, 1997 }\end{array}\right)$
}

\begin{abstract}
The effect of two anti-platelet drugs, ticlopidine and dilazep, on the fetal bovine serum (FBS)induced DNA synthesis of cultured rat renal mesangial cells was assessed by means of an $\left[{ }^{3} \mathrm{H}\right]$ thymidine incorporation assay. Each drug inhibited the $2 \%$ FBS-induced $\left[{ }^{3} \mathrm{H}\right]$ thymidine incorporation in a concentration-dependent manner, similar to the inhibition of dipyridamole. The $\left[{ }^{3} \mathrm{H}\right]$ thymidine incorporation was significantly suppressed by the treatment of more than $1 \mu \mathrm{M}$ ticlopidine or dilazep. It was thus suggested that ticlopidine and dilazep, might prevent the progression of such glomerular diseases as proliferative glomerulonephritis, at least in part, by suppressing mesangial cell proliferation.
\end{abstract}

Key words - ticlopidine, dilazep, dipyridamole, DNA synthesis, proliferation, rat mesangial cell

\section{Introduction}

Mesangial cells are a major constituent of the renal glomerulus and have complex biological functions. Their proliferation is believed to play an important role in the inflammatory response to glomerular injury, which is one of the general characteristics of various glomerular diseases, including proliferative glomerulonephritis, IgA nephropathy and diabetic nephropathy. Recently, there is much evidence that cultured mesangial cells become proliferative when incubated with various cytokines, vasoactive substances, hormones or reactive oxygen ${ }^{1-3)}$. The release of platelet-derived growth factor (PDGF) from platelets and the progress of coagulation by the activation of platelets are an important intermediate mechanism in glomerular inflammation and proliferation. Antiplatelet drugs such as dipyridamole, ticlopidine and dilazep have already been used on the treatment of glomerular inflammation and succeeded in the improvement of protein urea and blood urea. In particular, it has been reported that dipyridamole, a phosphodiesterase (PDE) inhibitor, inhibits the serum-induced DNA synthesis of cultured mesangial cells ${ }^{4}$. However, there has been no report on the effects of ticlopidine, a fibrinogen receptor antagonist and activator of adenylate cyclase, and dilazep, a phospholipase $\mathrm{A}_{2}$ (PLA $\mathrm{PA}_{2}$ inhibitor, on the proliferation of cultured mesangial cells. Therefore, we examined whether they, like dipyridamole, suppressed fetal bovine serum (FBS)-induced DNA synthesis of cultured rat renal mesangial cells by means of the $\left[{ }^{3} \mathrm{H}\right]$ thymidine

† 京都市山科区御陵中内町 $5 ;$ 5, Nakauchi-cho, Misasagi, Yamashina-ku, Kyoto, 607-8414 Japan 
incorporation assay.

\section{Materials and Methods}

\section{Materials}

RPMI 1640, Hanks' balanced salt solution (HBSS), and collagenase type I were purchased from Nissui (Tokyo, Japan) or Funakoshi (Tokyo, Japan). FBS (Lot No. 09017) was purchased from Bio Whittaker (MD, USA). $\left[{ }^{3} \mathrm{H}\right]$ Thymidine was purchased from Amersham International plc (Bucks, U.K.). Other chemicals were purchased from Wako Pure Chemical Ind. Ltd. (Osaka, Japan). Ticlopidine chloride (Lot No. 95/6138) was a gift from Daiichi Seiyaku Co., Ltd. (Tokyo, Japan). Dilazep hydrochloride (Lot No. 034571) was a gift from Kowa Shinyaku Co., Ltd. (Nagoya, Japan). Dipyridamole was purchased from Sigma Chemical Co. (St. Louis, MO, U.S.A.). All the other reagents were of the highest commercially available grade.

\section{Isolation and Culture of Mesangial Cells}

Glomerular mesangial cells were cultured from glomeruli by differential sieving as previously described by Kikkawa et al. ${ }^{5}$, and Kreisberg and Karnovsky ${ }^{6}$. In brief, glomeruli from six male Sprague-Dawley rats (110-120 g) were isolated by the standard sieving method. The glomeruli were incubated in HBSS with $750 \mathrm{U} / \mathrm{ml}$ of collagenase type $\mathrm{I}$ for about $10 \mathrm{~min}$ at $37^{\circ} \mathrm{C}$. Then, the glomerular cores were plated on culture dishes (i.d. : $90 \mathrm{~mm}$ ) in the RPMI 1640 medium supplemented with $20 \%$ FBS, $100 \mathrm{U} / \mathrm{ml}$ penicillin G (Meiji, Tokyo, Japan), $0.2 \mathrm{~g} / \mathrm{ml}$ streptomycin (Meiji, Tokyo, Japan), and ITS ${ }^{\mathrm{TM}}$ premix $(5 \mathrm{mg} / 1$ insulin, $5 \mathrm{mg} / 1$ transferrin and $5 \mu \mathrm{g} / 1$ selenious acid ; Becton Dickinson, Sparks, MD, USA). The dishes were kept in a humidified incubator at 37 ${ }^{\circ} \mathrm{C}$ under $95 \%$ air and $5 \% \mathrm{CO}_{2}$. After the glomeruli had attached to the plates and the cells had begun to grow, the culture medium was changed two times per week. Under these conditions homogeneous outgrowth of elongated or stellate cells occurred within 7 days, confluency being reached within 2 to 3 weeks. Mesangial cells were identified by checking their characteristic morphology under a phase-contrast microscope, and the specific binding/nonspecific binding ratio of angiotensin $I(\geq 10)^{5)}$, etc. Endothelial cells and resident glomerular macrophages are not viable under the growth conditions employed.

\section{3. $\left[{ }^{3} \mathrm{H}\right]$ Thymidine Incorporation Assay}

Mesangial cells at the third to sixth passage were used in this study. In the assay, the mesangial cells, at about $80 \%$ subconfluency, were trypsinized with a trypsin-EDTA solution $(0.5 \%$ trypsin and $5.3 \mathrm{mM}$ EDTA $4 \mathrm{Na}$; Gibco, Gaithersburg, MD, USA) diluted ten-fold with PBS for about 20 minutes at $37^{\circ} \mathrm{C}$. More than $95 \%$ of the cells used in this experiment were confirmed to be viable by the trypan blue exclusion test. Then, they were resuspended in the culture medium, their density was adjusted at $0.5 \times 10^{5} \mathrm{cells} / \mathrm{ml} /$ well, and they were cultured on a 6-well culture plate (Sumilon, Osaka, Japan) for $48 \mathrm{~h}$ at $37^{\circ} \mathrm{C}$ under $5 \% \mathrm{CO}_{2}$. Then, the cells were cultured in $0.5 \% \mathrm{BSA}$-RPMI 1640 medium for $48 \mathrm{~h}$ until they became quiescent. To assess the DNA synthesis of cells, the $\left[{ }^{3} \mathrm{H}\right]$ thymidine incorporation assay was performed at $24 \mathrm{~h}$ after the addition of $2 \% \mathrm{FBS}$ and/or a drug. $\left[{ }^{3} \mathrm{H}\right]$ Thymidine $(1 \mu \mathrm{Ci} / 10 \mu \mathrm{l} /$ well) was added to each well, followed by incubation for $4 \mathrm{~h}$ at 37 ${ }^{\circ} \mathrm{C}$ under $5 \% \mathrm{CO}_{2}$. Then, the cells were washed twice with PBS and then solubilized by adding 0.5 $\mathrm{ml}$ of $1 \mathrm{~N} \mathrm{NaOH}$. The solubilized cell solutions were neutralized with $0.5 \mathrm{ml}$ of $1 \mathrm{~N} \mathrm{HCl}$ and then added to $5 \mathrm{ml}$ of a scintillation cocktail. The radioactivity was measured with a liquid-scintillation 
counter (LSC-1000; Aloka, Tokyo, Japan) for 3 min per sample.

\section{Cell Counting}

Mesangial cells were trypsinized and then counted immediately using a hemocytometer (CLAY ADUMS $^{\circledR}$; Becton Dickinson, Sparks, MD, USA).

\section{Statistical Analysis}

Data are expressed as means \pm S.E. Statistical analysis was performed by means of analysis of variance (ANOVA, Bonnferroni/Dunn test) with Stat View J 4.02 for a Macintosh (Abacus Concepts, Inc., Berkeley, CA, USA). Differences were considered statistically significant at $p<0.05$.

\section{Results and Discussion}

It is known that the proliferation of mesangial cells is mediated by several factors such as cytokines, vasoactive substances and hormones ${ }^{1-3}$. In this study, we chose FBS as a mitogen, because it was one of the strongest mitogens for mesangial cells ${ }^{1)}$. On the other hand, the clinically effective concentrations of dipyridamole, ticlopidine and dilazep in blood at steady state are within the range from about 1 to $10 \mu \mathrm{M}$. None of the three drugs $(10 \mu \mathrm{M})$ had any significant effect on basal $\left[{ }^{3} \mathrm{H}\right]$ thymidine incorporation and viable cell number when FBS was absent (data not shown). Therefore, we established experimental concentrations of these drugs as $0.1-10 \mu \mathrm{M}$ in this study.

First, we investigated the effect of dipyridamole on FBS-induced DNA synthesis of mesangial cells by means of the $\left[{ }^{3} \mathrm{H}\right]$ thymidine incorporation assay in order to confirm the normality and utility of our cells (Fig. 1). One or $10 \mu \mathrm{M}$ of dipyridamole significantly reduced FBS-induced $\left[{ }^{3} \mathrm{H}\right]$ thymidine incorporation in a concentration-dependent manner $(2 \% \mathrm{FBS}, 650.0 \% ; 0.1 \mu \mathrm{M}, 670.5$ $\% ; 1 \mu \mathrm{M}, 148.9 \% ; 10 \mu \mathrm{M}, 34.4 \%)(p<0.0001)$. Additionally, cell morphology under phase-

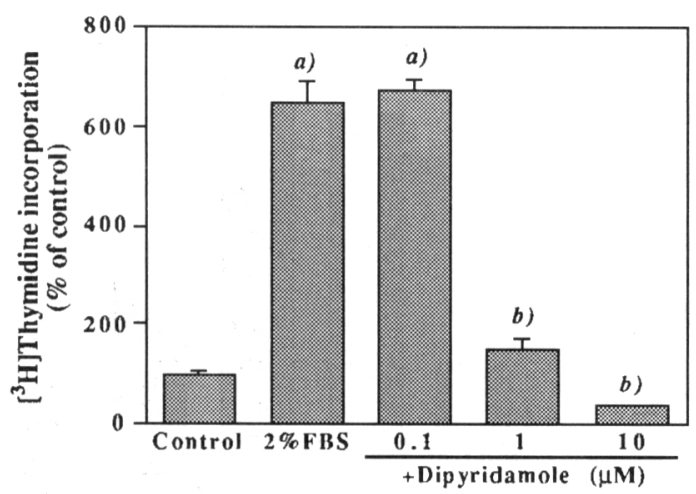

Fig. 1. Effect of Dipyridamole on FBS-Induced DNA Synthesis of Cultured Rat Mesangial Cells

After preculturing for 4 days, mesangial cells were cultured in either FBS-free (control), $2 \%$ FBS or $2 \%$ FBS plus dipyridamole $(0.1-10 \mu \mathrm{M})$ at $37^{\circ} \mathrm{C}$ under $5 \% \mathrm{CO}_{2}$. Then, the $\left[{ }^{3} \mathrm{H}\right]$ thymidine incorporation assay was performed at $24 \mathrm{~h}$ to assess the DNA synthesis. Each column is the percentage of radioactivity of $\left[{ }^{3} \mathrm{H}\right]$ thymidine incorporated in a parallel control, and represents the mean士S.E. $(\mathrm{n}=4)$. a) $p<$ 0.0001 significantly different from the value of control. b) $p<0.0001$ significantly different from the value of $2 \%$ FBS. 
contrast microscopy and viability were not altered by any concentrations of dipyridamole. This data was similar to that reported by Majima ${ }^{4)}$. From these results, the cells used in this experiment was found to be normal and utilizable.

It is generally known that intracellular signal transduction pathway regulates a variety of cellular processes. Particularly, mitogen-activated protein kinase (MAPK) phosphorylation cascade plays a multifunctional role in various cells ${ }^{7}$, and the activation of MAPK, which is induced by PDGF or epidermal growth factor (EGF), is responsible for the proliferation in the case of cultured mesangial cells ${ }^{8)}$. It has been shown that the suppression of the MAPK cascade is caused by the increase of cyclic adenosine 3',5'-monophosphate (cAMP) and subsequent activation of cAMP-dependent protein kinase (PKA) in several kinds of cells including cultured mesangial cells ${ }^{8-10)}$. Additionally, Matousovic et al. proved that $3 \mu \mathrm{M}$ cilostamide, a cAMP-PDE inhibitor similar to dipyridamole, decreased EGF-stimulated MAPK activity and DNA synthesis by activating cAMP-PKA pathway because of the inhibition of PDE, ultimately resulting in suppression of the proliferation of rat mesangial cells ${ }^{11}$. Accordingly, the mechanism of inhibitory effect of dipyridamole on FBS-induced DNA synthesis might be the same as that of cilostamide against the EGF-induced one. Furthemore, Tsuboi et al. showed that PDE antagonists suppress the proliferation of mesangial cells and the development of glomerulonephritis in rats with anti-rat thymocyte serum induced mesangioproliferative glomerulonephritis ${ }^{12)}$.

Next, the effect of ticlopidine, a fibrinogen receptor antagonist and activator of adenylate cyclase, on FBS-induced DNA synthesis of mesangial cells is shown in Fig. 2 . The FBS-induced $\left.{ }^{3} \mathrm{H}\right]$ thymidine incorporation was concentration-dependently suppressed by ticlopidine ( $2 \%$ FBS, 411.9 $\% ; 0.1 \mu \mathrm{M}, 460.5 \% ; 1 \mu \mathrm{M}, 230.0 \% ; 10 \mu \mathrm{M}, 48.8 \%)$. This anti-proliferative effect of ticlopidine was significant at doses of 1 and $10 \mu \mathrm{M}(p<0.0001)$. As the cell number was not changed by any

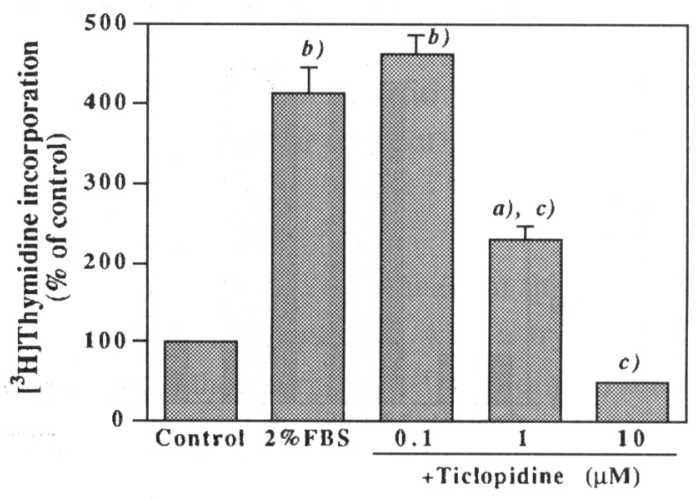

Fig. 2. Effect of Ticlopidine on FBS-Induced DNA Synthesis of Cultured Rat Mesangial Cells

After preculturing for 4 days, mesangial cells were cultured in either FBS-free (control), $2 \%$ FBS or $2 \%$ FBS plus ticlopidine $(0.1-10 \mu \mathrm{M})$ at $37^{\circ} \mathrm{C}$ under $5 \% \mathrm{CO}_{2}$. Then, the $\left[{ }^{3} \mathrm{H}\right]$ thymidine incorporation assay was performed at $24 \mathrm{~h}$ to assess the DNA synthesis. Each column is the percentage of radioactivity of $\left[{ }^{3} \mathrm{H}\right]$ thymidine incorporated in a parallel control, and represents the mean \pm S.E. $(\mathrm{n}=4)$. a) $p<$ 0.001 and b) $p<0.0001$ significantly different from the value of control. c) $p<$ 0.0001 significantly different from the value of $2 \%$ FBS. 
concentration of ticlopidine, and the cells were confirmed to be viable by trypan blue exclusion test, we judged that the cell toxicity was not also observed in this case.

The responses of platelets to agonists are believed to be mediated by at least two pertussis toxinsensitive guanine nucleotide-binding $(G)$ proteins coupling with receptors: Gi which inhibits adenylate cyclase, and $\mathrm{Gp}$ which stimulates phospholipase $\mathrm{C}$. Thrombin and ADP have both been shown to inhibit adenylate cyclase in platelets in a Gi-dependent manner ${ }^{13,14}$. Ticlopidine is speculated to increase adenylate cyclase activity and inhibit ADP-induced platelet aggregation by impairing the interaction between Gi and the ADP receptor ${ }^{15}$. Ticlopidine is metabolized endogenously and its anti-aggregating activity against platelets is due to one or more unstable metabolites ${ }^{16)}$. This is suggested by the fact that it causes an inhibition of platelet aggregation only when taken orally, but shows only very low in vitro anti-aggregating activity ${ }^{16)}$. But, in the case of mesangial cells, ticlopidine showed anti-proliferative activity even in vitro. From these facts, its mechanism of antiproliferative action against mesangial cells may differ from that of anti-aggregating effect against platelets, but its inhibitory mechanism of action is now unclear.

Third, the effect of dilazep, a PLA 2 inhibitor, on FBS-induced DNA synthesis of the cells was evaluated. As shown in Fig. 3, FBS-induced $\left[{ }^{3} \mathrm{H}\right]$ thymidine incorporation was reduced by dilazep in a concentration-dependent manner (2\% FBS, 903.8\%; $0.1 \mu \mathrm{M}, 943.7 \% ; 1 \mu \mathrm{M}, 427.0 \% ; 10$ $\mu \mathrm{M}, 112.0 \%)$. This anti-proliferative effect of dilazep was significant at doses of 1 and $10 \mu \mathrm{M}(p$ $<0.0001)$.

Dilazep decreases the production of thromboxane $\mathrm{A}_{2}$ in platelets by suppressing PLA $\mathrm{A}_{2}$ that is related to the release of arachidonic acid, leading to the inhibition of platelet aggregation. There has been no reports on the relationship between the function of $\mathrm{PLA}_{2}$ and proliferation of cultured mesangial cells now. So, the mechanism of anti-proliferative effect of dilazep as well as that of ti-

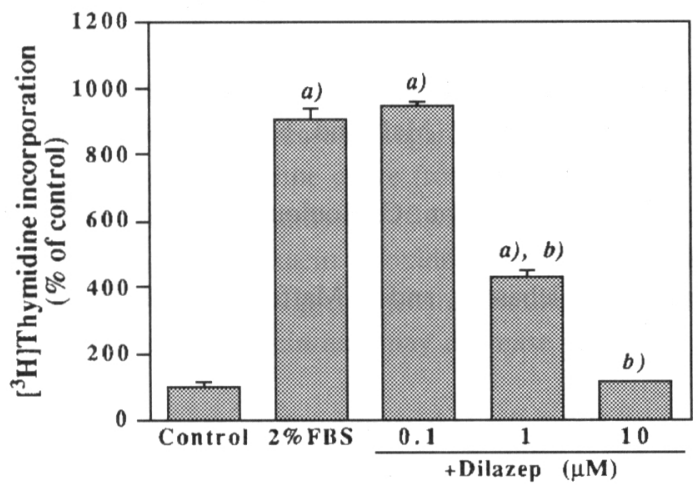

Fig. 3. Effect of Dilazep on FBS-Induced DNA Synthesis of Cultured Rat Mesangial Cells After preculturing for 4 days, mesangial cells were cultured in either FBS-free (control), $2 \%$ FBS or $2 \%$ FBS plus dilazep $(0.1-10 \mu \mathrm{M})$ at $37^{\circ} \mathrm{C}$ under $5 \% \mathrm{CO}_{2}$. Then, the $\left[{ }^{3} \mathrm{H}\right]$ thymidine incorporation assay was performed at $24 \mathrm{~h}$ to assess the DNA synthesis. Each column is the percentage of radioactivity of $\left[{ }^{3} \mathrm{H}\right]$ thymidine incorporated in a parallel control, and represents the mean \pm S.E. $(n=4)$. a) $p<0.0001$ significantly different from the value of control. b) $p<0.0001$ significantly different from the value of $2 \%$ FBS. 
clopidine remains unclear. In order to elucidate their mechanisms of action, further studies are in progress by examining the effect of both drugs on various stimulants (PDGF, EGF, phorbol ester, et al.) -induced DNA synthesis and MAPK activation in cultured mesangial cells.

In conclusion, it was suggested that ticlopidine and dilazep, might prevent the progression of glomerular diseases such as proliferative glomerulonephritis, at least in part, by suppressing mesangial cell proliferation.

\section{Acknowledgments}

We thank Daiichi Seiyaku Co., Ltd. and Kowa Shinyaku Co., Ltd., for the kind gifts of ticlopidine chloride and dilazep hydrochloride, respectively.

\section{References}

1) P. Mené, M. S. Simonson, and M. J. Dunn, Physiol. Rev., 69, 1347-1424 (1989).

2) L. J. Striker, E. P. Peten, S. J. Elliot, T. Doi, and G. E. Striker, Lab. Invest., 64, 446-456 (1991).

3) D. H. Lovett and R. B. Sterzel, Kidney Int., 30, 246-254 (1986).

4) K. Majima, Kurume Igakukai Zasshi, 56, 805-818 (1993).

5) R. Kikkawa, K. Umemura, M. Haneda, T. Arimura, K. Ebata, and Y. Shigeta, Diabetes, 36, 240-243 (1987).

6) J. I. Kreisberg and M. J. Karnovsky, Kidney Int., 23, 439-447 (1983).

7) J. Blenis, Proc. Natl. Acad. Sci. USA, 90, 5889-5892 (1993).

8) X. Li, F. Zarinetchi, R. W. Schrier, and R. A. Nemenoff, Am. J. Physiol ., 269, C986-C991 (1995).

9) J.Wu, P. Dent, T. Jelinek, A. Wolfman, M. J. Weber, and T. W. Sturgill, Science, 262, 1065-1069 (1993).

10) S. J. Cook and F. McCormick, Science, 262, 1069-1072 (1993).

11) K. Matousovic, J. P. Grande, C. C. S. Chini, E. N. Chini, and T. P. Dousa, J. Clin. Invest., 96, 401-410 (1995).

12) Y. Tsuboi, S. J. Shankland, J. P. Grande, H. J. Walker, R. J. Johnson, and T. P. Dousa, J. Clin. Invest., 98, 262-270 (1996).

13) L. F. Brass, M. J. Woolkalis, and D. R. Manning, J. Biol. Chem., 263, 5348-5355 (1988).

14) C. Gachet, P. Savi, P. Ohlmann, J. -P. Maffrand, K. H. Jakobs, and J. -P. Gazenave, Thrombosis and Haemostasis, 68, 79-83 (1992).

15) C. Gachet, J. -P. Cazenave, P. Ohlmann, C. Bouloux, C. Defreyn, F. Driot, and J. -P. Maffrand, Biochem. Pharmacol., 40, 2683-2687 (1990).

16) G. Defreyn, A. Bernat, D. Delebassee, and J. Maffrand, Seminars in Thrombosis and Hemostasis, 15, 159-166 (1989). 